\title{
F. M. Alexander, the Use of the Self, and a 1932 Book Review + Discussion in the Yorkshire Post: A Failure to Impact Medical Science.
}

\author{
Author Details: \\ Jeroen Staring-Dr Jeroen Staring teaches mathematics at secondary schools in The Netherlands. His 2005 Medical \\ Sciences dissertation describes the life, work and technique of F. Matthias Alexander. In 2013 he successfully \\ defended a second dissertation, on the early history of the NYC Bureau of Educational Experiments. \\ The author wishes to acknowledge assistance by the (2003-2004) archivist at the Special Collections at the Wessell \\ Library, Tufts University, Medford, U.S.A.
}

\section{Abstract}

In 1931, Frederick Matthias Alexander, founding father of the Alexander Technique, who in 1894 began a career as a full-time stage artist and elocution and breathing teacher launched his book The Use of the Self explaining the history of his discovery of what he called a "primary control of the psycho-physical mechanisms" (Alexander, 1932c). This case study critically describes the chronicle of Alexander's claim, notably citing the full text of a yet unreferenced letter to the editor of the Yorkshire Post written by Alexander in reaction to a book review by the young journalist Charles Davy. The case study shows how Alexander and his followers developed a strategy of self-sought isolation.

Key Words: Edgar Douglas Adrian (1889-1977), F. Matthias Alexander (1869-1955), Charles Davy (1897-1985), John Dewey (1859-1952), Ellen Avery Margaret Goldie (1905-1997), Ernst Franz Jokl (1907-1997), David Alexander Cecil Low (1891-1963), Rudolf Magnus (1873-1927), Caleb Williams Saleeby (1878-1940), Irene Tasker (1887-1977), 'central control, ' 'conscious control,' 'primary control.'

\section{Introduction}

When Frederick Matthias Alexander - Specialist in Respiration (Alexander, n.d.) and future founding father of the self-styled 'Alexander Technique' — spent winters in New York City between 1916 and 1924 (Staring, 2015), American philosopher John Dewey had lessons with him in vocal and respiratory 'reeducation' and 'conscious control' (Alexander, 1907, 1912). Dewey was pleased with the results. He wrote lyrical introductions to two of Alexander's books (Dewey, 1918, 1923). In 1926, when in England, he frequented Alexander's London practice for two days of lessons. Three years later, in the spring of 1929, Dewey was giving a series of lectures in Edinburgh, Scotland, and may have met Alexander again. Yet, in the fall of that year, at Dewey's seventieth birthday in October, Alexander and Dewey certainly met. Alexander crossed the Atlantic to attend the birthday festivities in New York City.

Less than a month later, the 1929 Wall Street Crash hit the world — including Alexander. His stocks terribly reduced in value. In London (England), there was a sharp decline in the number of clients seeking his services. He even had to sell off his stable of racehorses. More dark clouds filled the skies. Alexander's marriage was failing. His wife and adopted daughter left their Bexleyheath, Kent home, moving to a flat in London. Bloch (2004) suggests that Alexander's wife was jealous of the women surrounding her husband as his servants and as assistants at his London practice - together with his Little School, a small school for children with special educational needs who could benefit from his instruction. There must be truth in Bloch's story, because at some time during the late 1920s Alexander had begun a relationship with his housekeeper, who on June 12, 1931, gave birth to a son, who in 1985 in a Sydney, Australia newspaper revealed that he was Alexander's natural son (Casey, 1985; Staring, 1990).

In 1930, Alexander's financial situation rapidly deteriorated from bad to worse. He had to devise alternative means to provide for his livelihood, including his servants and assistants.

\section{The Use of the Self (1931)}

Frederick Matthias Alexander's plan to sincerely address his financial problems amounted to advancing a total program of launching a new book, training aspirant teachers for his Little School for children with special educational needs, as well as at the same time training candidate teachers in his 'technique.' 


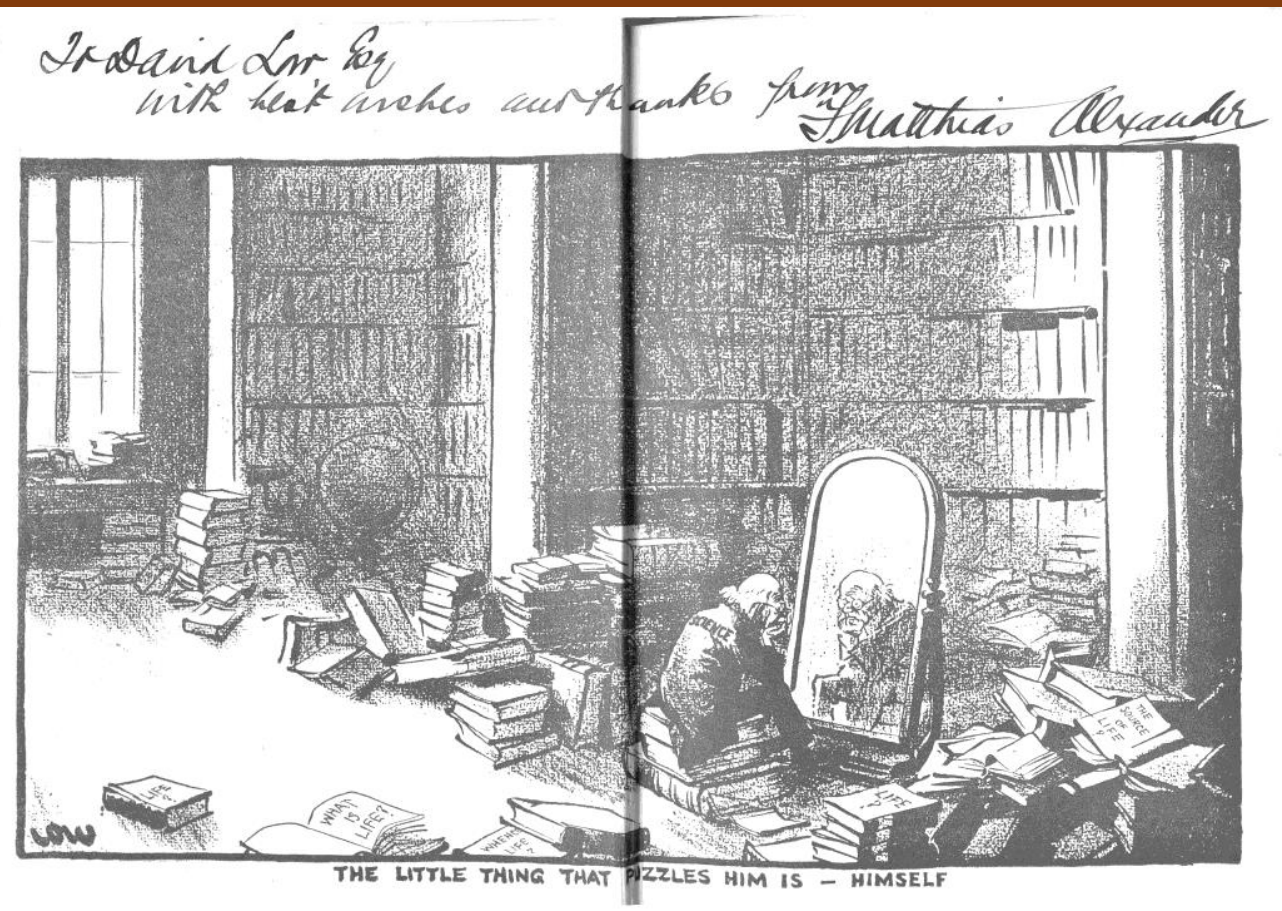

Figure 1. F. M. Alexander's inscription in David Low's copy of the 1931 U.K. edition of The Use of the Self. Political cartoonist Sir David Alexander Cecil Low drew the above illustration. Until today, this copy remained uncut. (Jeroen Staring Collection).

The Use of the Self, Alexander's new book, was released in the fall of 1931. In the 'Appendix,' Alexander (1931) recounted a romanticized story of his decision to establish a teachers training course. Noting the 1924 to 1931 development of his Little School, he explained the need for a training course for teachers of his special methods. He wrote he would train students for eighteen months before they would be able to help in the Little School, enabling the children with special educational needs to make more progress in a given time. Additionally, he reproduced a July 22, 1930, letter he sent to his devotees and intending students, stating that he had in the past "devoted much time and thought to the working out of satisfactory means whereby students can be trained to impart the technique set down" (p. 125). He had hesitated long, he claimed, but eventually decided to "start a course for the training of teachers" (p. 126), referring to Dewey's comments in the 'Introduction' to his 1923 book Constructive Conscious Control of the Individual, and publishing a number of congratulating letters, which advised him to begin a training course. Next, Alexander declared that he had had clients from all over the world, indicating intending students would certainly not remain jobless once they were certified. He announced that "two substantial donations have been promised towards the formation of a Trust Fund for the establishment in the future of a school in which the teaching posts will be filled by those who are competent to teach in accordance with the technique in [his] books" (p. 133), adding, "At the date of going to press the first payments to the Trust Fund have been made by the generous donors and we have the promise of future support from others" (p. 136).

The training course began in March 1931 (see: Alexander, 1931, p. viii). Eight students embarked on the adventure, in the next three years to be joined by five colleague students, among whom two family members of Alexander's (Staring, 2005).

The F. Matthias Alexander Trust Fund was officially inaugurated in 1933. Two years later, the Fund published a 20-page pamphlet called A New Technique Employed in Acquiring an Improved Use of the Self while Learning and Learning to Do, explaining its purpose.

\section{John Dewey's Introduction}

In his 'Introduction' to The Use of the Self, Alexander's American client John Dewey (1931) stated that "Mr. Alexander created what may be truly called a physiology of the living organism" (p. xiv), claiming that "the conclusions of Mr. Alexander's experimental inquiries are in harmony with what physiologists know about the muscular and nervous structure" (p. $x v$ ). Dewey referred to German pharmacologist and 
physiologist Rudolf Magnus, Professor of pharmacology at the University of Utrecht in Utrecht, The Netherlands, declaring,

Magnus proved by means of what may be called external evidence the existence of a central control in the organism. But Mr. Alexander's technique gave a direct and intimate confirmation in personal experience of the fact of central control long before Magnus carried on his investigations. And one who has had experience of the technique knows it through the series of experiences which he himself has. The genuinely scientific character of Mr. Alexander's teaching and discoveries can be safely rested upon this fact alone. (pp. xv-xvi; emphasis added).

Dewey further wrote that every lesson with Alexander was "a laboratory experimental demonstration" (p. $x v i)$, affixing his view that

The discovery of a central control which conditions all other reactions brings the conditioning factor under conscious direction and enables the individual through his own co-ordinated activities to take possession of his own potentialities. It converts the fact of conditioned reflexes from a principle of external enslavement into a means of vital freedom... The technique of Mr. Alexander gives to the educator a standard of psychophysical health - in which what we call morality is included... It bears the same relation to education that education itself bears to all other human activities. (pp. xviii-xix).

\section{Alexander's Narrative of the Evolution of his Technique}

The Use of the Self opens with 'Evolution of a Technique,' a chapter that exhaustively tells Frederick Matthias Alexander's narrative of discovering his 'technique' by sketching a history of the steps he purportedly took to overcome breathing and reciting difficulties (see also: Starch, Stanton, \& Koerth, (Eds.), 1936). Students at the training course and Alexander's clients would now be enabled to examine their own difficulties in the light of Alexander's methods. Alexander's 1931 account of developing his 'technique' was not unknown to his readers in the United Kingdom. For instance, in March 1927, the English newspaper The Daily Chronicle published a letter to the editor, signed by H. F., titled "Is It Our Own Fault?" In essence the letter summarizes Alexander's story as later published in the 1931 The Use of the Self. "He spent hundreds of hours studying himself in a large looking-glass; he came to the conclusion that there is a right way and a wrong way of doing everything." The letter's author rather impulsively predicted, "[Alexander's] influence is discernible already. He may end by revolutionizing medical science" (H. F., 1927). In November 1928, Alexander's story had again been told, less roughly, in a book review in the New Age magazine:

Mr. Alexander is an Australian...who began his method as the result of hard experience. He was an elocutionist and an actor. Suffering from clergyman's sore throat, he went to a doctor, was sprayed and drugged, and was cured. When he came to recite again, however, he got the throat again; but when his doctor proposed to give the mixture as before, he saved his money on the common sense ground that what he really wanted was to know how to use his vocal organs so as not to inflame them. With the aid of a mirror he studied how he made himself hoarse - and stopped doing it. He went farther; he watched other movements, how he stood, sat, walked, etc., and came to the conclusion that, viewed from a detached point of view, his body, though he felt it to be right, was a very ill-working and power-wasting contrivance. He saw possibilities in psycho-physical re-education and saw the reasons for its necessity. He began to develop a system for teaching badly co-ordinated mind-bodies how to get work out of themselves without wearing themselves out in friction. (R. M., 1928, p. 31).

Hence, the spirit of the 1931 narrative was already known before The Use of the Self was launched. Alexander's (later) student Frank Pierce Jones (1979) suggested that Alexander wrote the first chapter in The Use of the Self in "consent" to Dewey's request for a detailed account of the "self-observations and experiments" that led to developing the Alexander Technique (p. 45). Dewey must have known that Alexander's narrative circulated in the U.K. Still, the 1931 The Use of the Self adds many details — which will not all be examined here.

Alexander (1931) wrote in The Use of the Self that he became convinced that a "wrong way of using [him] self-constituted a combined wrong use of the whole of [his] physical-mental mechanisms" (p. 19). He claimed he discovered that when he was moving and using himself habitually this felt natural to him. He depended completely upon his "feeling" (p. 20), and he deduced that his "feeling" guided the way he was moving and using himself. He therefore stated that his "feeling" was untrustworthy as a means of "directing 
[his] use" (p. 32). He said to himself: "Surely...if it is possible for feeling to become untrustworthy as a means of direction, it should also be possible to make it trustworthy again" (p. 21), becoming aware that he confronted a paradox. His "feeling" needed to mediate and bear out that he was lengthening his stature, widening his back, not pulling his head back and down, but putting it forward and up instead, not gripping the floor, not bringing himself out of balance, but he could not trust his "feeling" at all. The only solution which presented itself was not to rely upon "feeling" associated with his "instinctive control and direction of use," and "in its place employ my reasoning processes, in order (1) to analyse the conditions of use present; (2) to select (reason out) the means whereby a more satisfactory use could be brought about; (3) to project consciously the directions required for putting these means into effect" (p. 25).

Alexander told himself to replace his "old instinctive (unreasoned) direction" (p. 25) of using, carrying and moving himself by a "new conscious (reasoned) direction" (p. 25) of using, carrying and moving himself. He, however, encountered the problem that there actually was no clear dividing line between the two kinds of directing. When he tried to do the reasoned out directions of using, carrying and moving himself (and speak at the same time) he immediately reverted to his old habitual ways of using, carrying and moving himself. So, the stimulus to use, bear and move himself his habitual way overshadowed the stimulus of trying to achieve new ways of using, carrying and moving himself once he had decided to execute what he wanted to do. His provisional conclusion in his own words:

I could see it actually happening in the mirror. This was clear proof that at the critical moment when I attempted to gain my end by means which were contrary to those associated with my old habits of use, my instinctive direction dominated my reasoning direction. It dominated my will to do what I had decided was the right thing to do, and although I was trying (as we understand "trying") to do it. (pp. 26-27).

The reasoned out three-step method failed completely, discouraging his efforts. Alexander had to alter his method again. He somehow had to distinguish, to split apart, the very close association of his "feeling" and his "doing." This time he decided to practise giving himself "directions" for the new, thought out, reasoned out, "means-whereby" (p. 28) - which meant inhibiting the habitual way(s) of using, carrying and moving of himself, and "projecting conscious directions" (p. 31) necessary to use, bear and move differently - instead of just trying, and merely doing, what he had decided was the right thing to do, and relating the whole process to the intended end, that was in his case, speaking. So he practised, for days, weeks, probably even months, in front of the mirror, not — immediately — doing, "inhibiting" (p. 64) and "projecting" what he wanted to do.

This experience taught me (1) that before attempting to "do" even the first part of the new "means-whereby" which I had decided to employ in order to gain my end (i.e. vocal use and reciting), I must give the directions preparatory to the doing of this first part very many times; (2) that I must continue to give the directions preparatory to the doing of the first part while I gave the directions preparatory to the doing of the second part; (3) that I must continue to give the directions preparatory to the doing of the first and second parts while I gave the directions preparatory to the doing of the third part; and so on for the doing of the fourth and other parts as required. (p. 28).

When he — at last — tried to execute the mentally practised "directions," however, Alexander found out that this method failed as well. He then concluded that his "inherited instinctive direction associated with [his] old habitual use" (p. 31; emphasis added) still dominated, and that his "sensory experiences" (p. 31) could by no means whatsoever be judged as 'right' or 'wrong.' Obviously, he reported concluding, he must have been relying - in an unconscious manner - upon his "feeling" all the time he had been experimenting with himself. Had everything been in vain? The moment — the critical moment — he started to execute the way(s) of using, carrying and moving himself he had carefully thought out, and prepared for by giving himself the necessary 'directions' - mentally, in silence — to execute the process(es) he had reasoned out, the attempt proved futile again. Alexander now adopted a plan to combat that peculiar critical moment.

Supposing that the "end" I decided to work for was to speak a certain sentence, I would start in the same way as before and (1) inhibit any immediate response to the stimulus to speak the sentence, (2) project in their sequence the directions for the primary control which I had reasoned out as being best for the purpose of bringing about the new and improved use of myself in speaking, and (3) continue to project these directions 
until I believed I was sufficiently au fait with them to employ them for the purpose of gaining my end and speaking the sentence.

At this moment, the moment that had always proved critical for me because it was then that I tended to revert to my wrong habitual use, I would change my usual procedure and (4) while still continuing to project the directions for the new use I would stop and consciously reconsider my first decision, and ask myself "Shall I after all go on to gain the end I have decided upon and speak the sentence? Or shall I not? Or shall I go on to gain some other end altogether?" - and then and there make a fresh decision, (5) either not to gain my original end, in which case I would continue to project the directions for maintaining the new use and not go on to speak the sentence; or to change my end and do something different, say, lift my hand instead of speaking the sentence, in which case I would continue to project the directions for maintaining the new use to carry out this last decision and lift my hand; or to go on after all and gain my original end, in which case I would continue to project the directions for maintaining the new use to speak the sentence. (pp. 33-34).

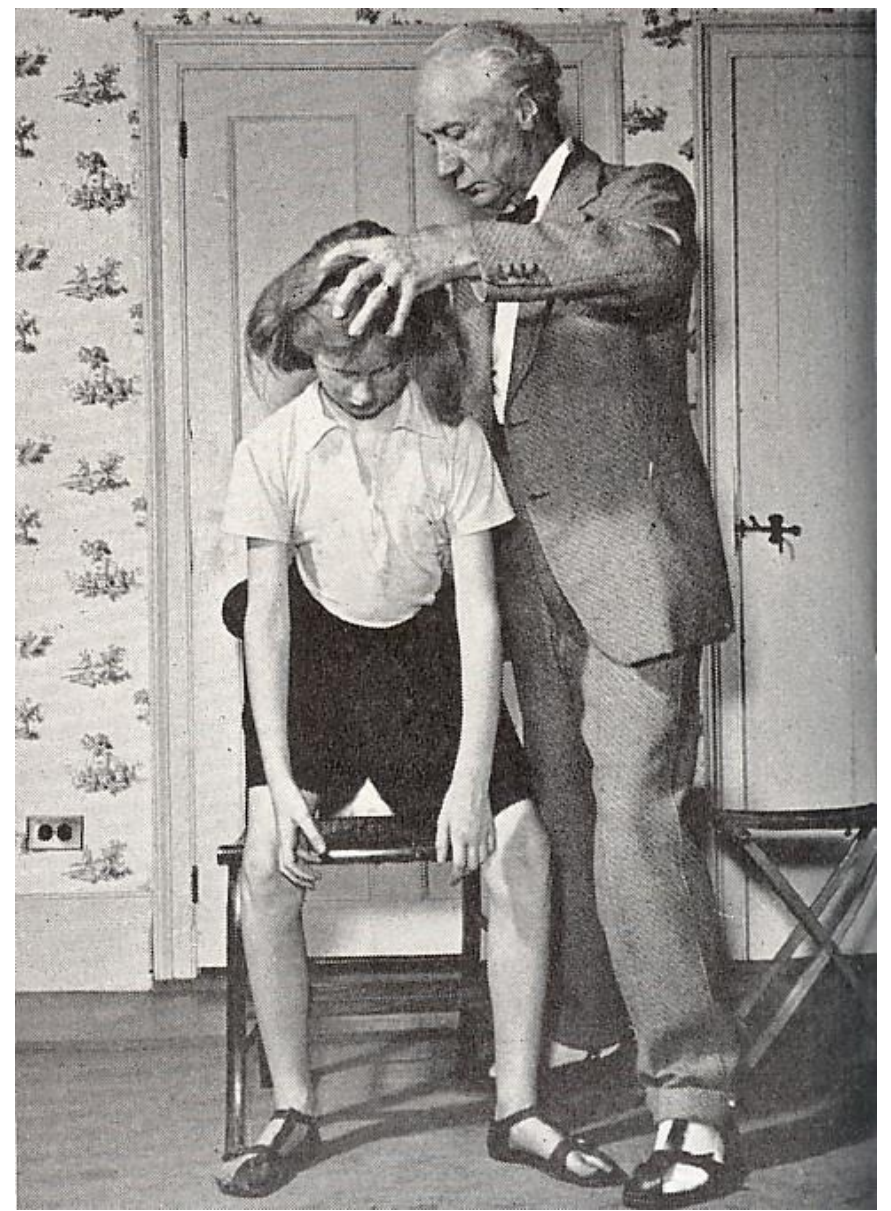

Figure 2. F. Matthias Alexander teaching a girl. Originally published in the September 1941 Who. (Jeroen Staring Collection).

This inhibition procedure worked. At last Alexander was successful. He claimed he had finally solved his throat and voice production problems by finding better ways of using, carrying and moving himself.

Interestingly, the procedure in essence boils down to what celebrated London singing teacher William Shakespeare (1924) had already described seven years earlier, when indicating a similar procedure of indirect control, however, in an extremely condensed way:

Some years ago I was practicing a difficult passage with small success - the notes would not join rightly. However, on turning my eyes round the corner to watch something that attracted my attention, I found then, to my amazement, that I could not sing the passage wrongly. This fact I have treasured in my mind ever since, and have constantly passed it on to my pupils" (p. 58). 
As well, Alexander's ideas of inhibition unmistakably reflect Caleb W. Saleeby's (1904) case study on the subject of volition and inhibition while playing cricket - instead of playing golf, as in Alexander's case study in the third chapter in The Use of the Self. Saleeby wrote, "As far as I can see it, the truth appears to be that the real willing is - to use a paradox - the negation of willing, the will not to, the control of the reflex act, or what the psychologists call inhibition" (p. 45). English eugenicist and founder of the Eugenics Education Society Caleb W. Saleeby - as Editor responsible for the "New Library of Medicine" at Alexander's publisher Methuen in London (Eugenical News, 1916) - had exclusively aided Alexander in publishing Man's Supreme Inheritance in 1910.

Furthermore, Alexander had on the face of it managed to solve his throat and voice production problems. Yet, if he had done what he wrote, he managed to do so in spite of clear-cut contradictions in theorizing. He stated he had trusted his observations in the mirror(s) - that is, the "feelings" or "sensory experiences" (Alexander's words) of his eyes, that is, his ocular sense organs. While collapsing the meaning of "feeling" and "sensory experience" in the first chapter of his 1931 book, he completely contradicted his own theory on the untrustworthiness of "feeling," meaning 'sensing,' undermining the core of his story.

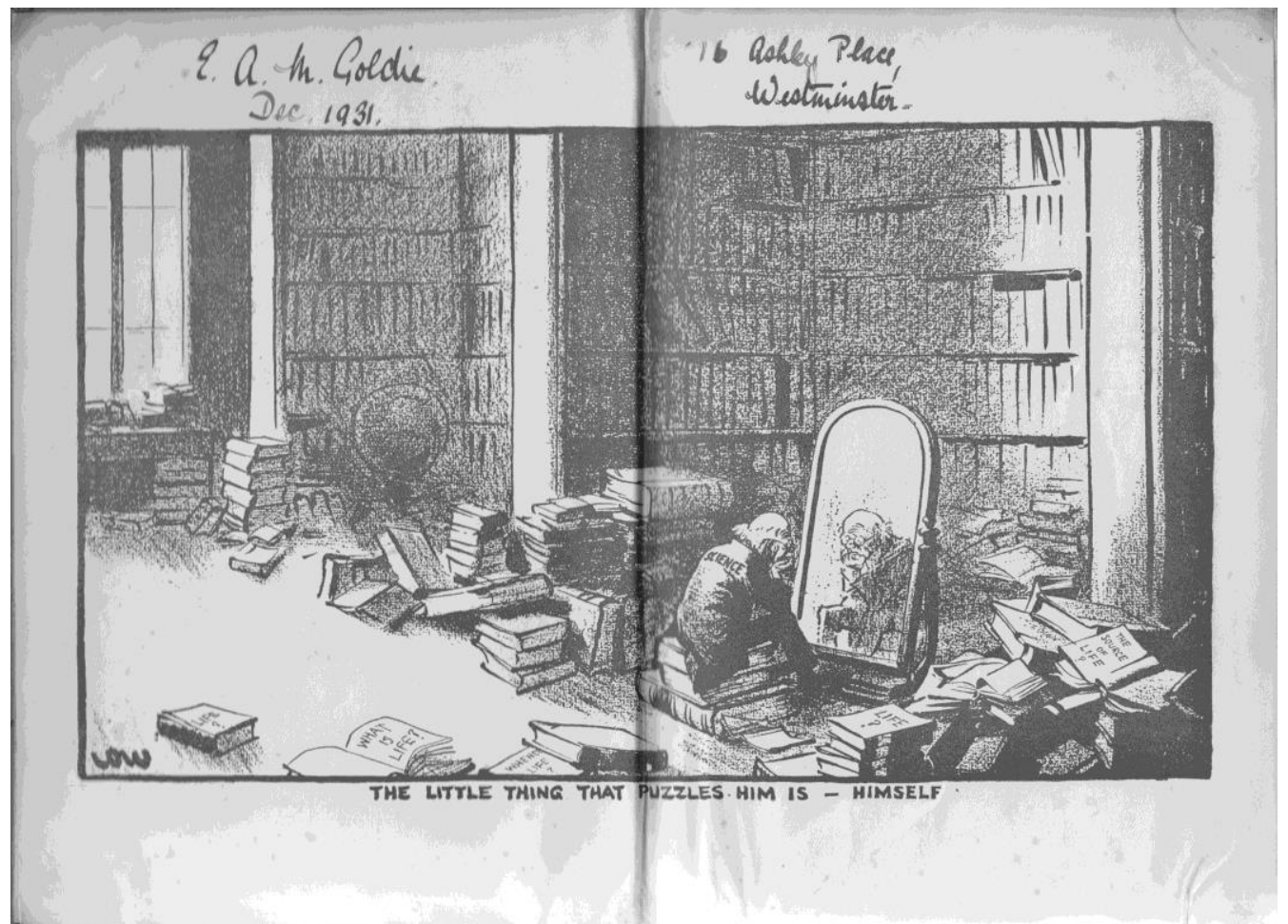

Figure 3. Margaret Goldie's inscription in her copy of the 1931 U.K. edition of The Use of the Self. (Jeroen Staring Collection). In 1929, Miss E. A. M. Goldie started working as a teacher at Alexander's Little School (see: Alexander, 1931, p. 124).

Note also that the first chapter in The Use of the Self is not an on-the-spot report of experiments, and certainly not an example of Best Evidence-based Practice research, nor does it give any exact reproductions of notes taken during Alexander's alleged (1890s') experiments, or of later experiments with others, nor can it, therefore, and because of other research methodological reasons, be categorized as historically accurate, or scientifically valid (as declared by Dewey in his 'Introduction' to The Use of the Self; see above). Basically, the first chapter in Alexander's The Use of the Self is a nice story, not more, not less.

Last but not least, according to Chicago based Alexander Technique teacher Ed Bouchard (personal communication), a participation by Alexander's assistant and 1924-1929 head of his Little School Irene Tasker in assisting Alexander with writing The Use of the Self can account for Jones's observation that the first chapter in The Use of the Self is "an exemplar of all the major steps that, according to Dewey, are characteristic of a scientific inquiry" (Jones, 1979, p. 45). Dewey had first outlined these steps in his 1910 How We Think; they are "( i) felt difficulty; (ii) its location and definition;" (iii) suggestion of possible solution; (iv) development by reasoning of the bearings of the suggestion; and ( $v$ ) further observation and 
experiment leading to its acceptance or rejection" (p. 72). Alexander probably attempted to cast the discovery narrative in the light of Dewey's 1910 understanding of science, as it in turn was understood by Alexander himself, and more specifically by his assistant Tasker — his silent partner-in-writing who in 1917 and 1918 had attended Dewey's advanced child psychology and pedagogy classes at Teachers College, Columbia University, New York City (Christian Advocate, 1918; Staring, Bouchard, \& Aldridge, 2014).

\section{Primary Control Central Control}

The next three chapters in The Use of the Self explain again Frederick Matthias Alexander's principles the second chapter in a general sense, the third and fourth through discussing difficulties experienced by a golfer and a stutterer. 'Diagnosis and Medical Training,' the final chapter, has Alexander's advice for physicians. The middle three chapters explain 'primary control' and 'central control' — two concepts brought up by Dewey in his 'Introduction' (see: Dewey, 1931, p. xv, xvii). Alexander (1931) had already used the first concept in the first chapter of The Use of the Self (pp. 11, 14, 23, 33), yet he had not delivered a definition. In the third chapter, he defined the 'primary control' and 'central control' concepts as follows:

This primary control, called by the late Professor Magnus of Utrecht the "central control," depends upon a certain use of the head and neck in relation to the use of the rest of the body, and once the pupil has inhibited the instinctive misdirection leading to his faulty habitual use, the teacher must begin the process of building up the new use by giving the pupil the primary direction towards the establishment of this primary control. (p. 60).

Alexander (1925) had first outlined the concept of 'primary control' in "An Unrecognized Principle in Human Behaviour," a lecture delivered in February 1925 before the London Child-Study Society. He quoted Dewey saying to him after having read the manuscript of his 1923 book Constructive Conscious Control of the Individual how well his procedures put into practice the five-thousand-year-old Chinese philosophy of non-doing. However, unfortunately, people had reached a state of affairs where they use their organism as if under "subordinate controls" (p. 7). Alexander proposed to use the concept of 'central control' to describe the technique he had developed. He claimed that Magnus had "worked to explain the scientific significance...in connection with that very control" that he had been using for twenty-five years (p. 8). He also used the concept of 'primary control' for the first time while explaining 'central control:' "The direction of the head and neck being of primary importance, [Magnus] found, as I found, that if we get the right direction from this primary control, the control of the rest of the organism is a simple matter" (p. 8; emphasis added).

The English phrase 'central control' in Alexander's book stems from his medical client Mungo Douglas having translated Rudolf Magnus's (1924) German phrase “Zentralapparat” (e.g., pp. 595, 619). Later in 1925, Alexander's medical client Macleod Yearsley, who had invited Alexander to lecture at the London Child-Study Society, published an article in the Literary Guide and Rationalist Review. The text of the article was added to a small advertisement for Alexander's books and distributed as a pamphlet. Yearsley praised Alexander's theorizing, declaring that Magnus's findings correspond to Alexander's. Amazingly, six years preceding (the title of) Alexander's 1931 The Use of the Self, Yearsley already used the phrase 'the use of the self.'

Further, [Alexander's] technique provides for our psycho-physical attitude towards the familiar and simple things of life, for it is a practical process of reasoning from the known to the unknown, first in regard to the use of the psycho-physical self, and then in connection with the use of the self in meeting the demands of every-day life in the ever-changing environment of civilization. This relation to environment demands a technique in which direction and guidance shall be built up consciously and constructively, employing the real central control in the use of the self in human activity. It must be emphasized that the central control thus employed is that advocated by Magnus. (Yearsley, 1925, p. 2; emphasis added).

Alexander never referenced Yearsley (1925) using the phrase "the use of the self."

Given that since 1925 a number of Alexander's clients (e.g., Ludovici, 1933, 1945; Macdonald, 1936; Rugg-Gunn, 1940) started referring to Magnus in their publications on Alexander, his discovery narrative and his procedures, it is very likely that they had jointly discussed the issue and agreed upon its interpretation. 


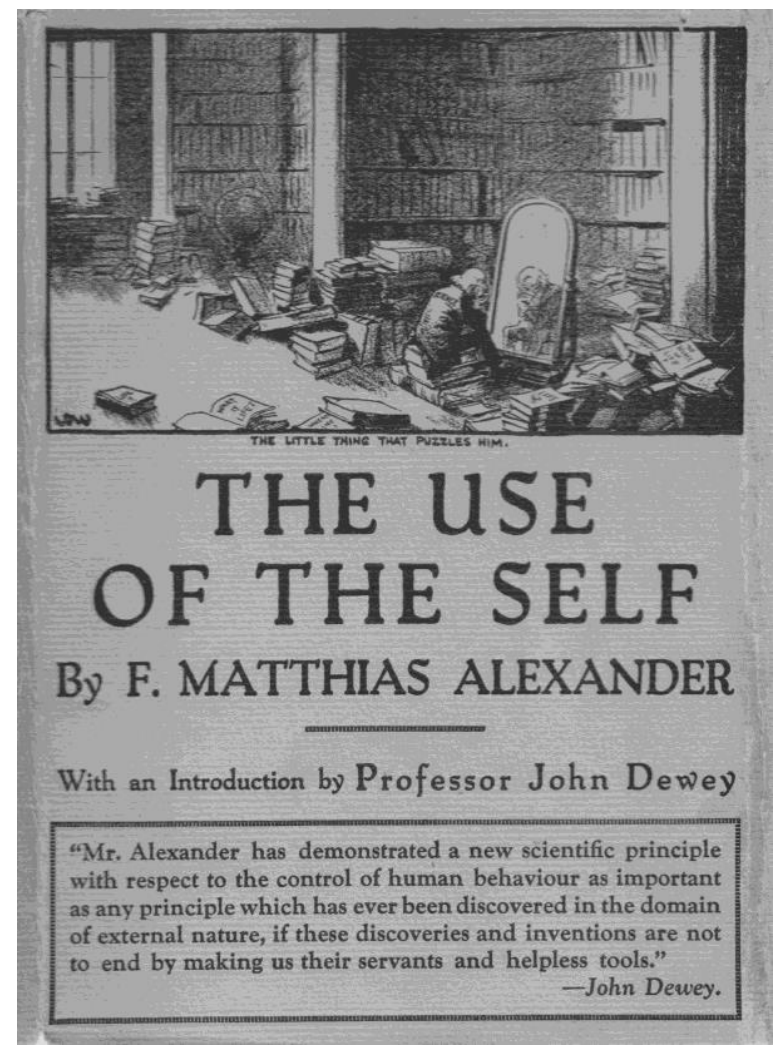

Figure 4. Front of dust jacket of the January 1932 U.S. edition of The Use of the Self. (Jeroen Staring Collection).

The later reification of Alexander's concept of 'primary control' into a notion of an essentially fixed and frozen 'head-neck-back-relationship' unavoidably led to confusion in the Alexander Technique practice and literature (Bloch, 2004; Williamson, 2014). Perhaps Alexander himself was to blame there, as is exposed in a quote from a letter, possibly dating from December 1945, to his American former student Frank Pierce Jones, in which he tried to redefine the original 1931 definition. Alexander (1931) originally stated that 'primary control' depends upon a relativity of 'use' of body parts: "a certain use of the head and neck in relation to the use of the rest of the body" (p. 60). In 1945, "primary control' did not depend anymore upon a relativity of 'use' of body parts. Alexander had changed the definition; 'primary control' now is, or equals, a relativity of body parts themselves: "The primary control of the use of ourselves in the activity of living may be most accurately defined as that relativity of the head to the neck and the head and neck to the body at a given time which makes for the integrated use of the mechanisms of the self as an indivisible whole" (Alexander, 1945). What this new definition may mean in medical science, physiotherapy or pedagogy is indistinct. It must be evident, however, that Alexander almost certainly taught his students and clients about the new definition, creating, in so doing, a root of the present-day reification of the 'primary control' concept as representing a kind of immobile 'head-neck-back-relationship.' 
Alexander and Magnus

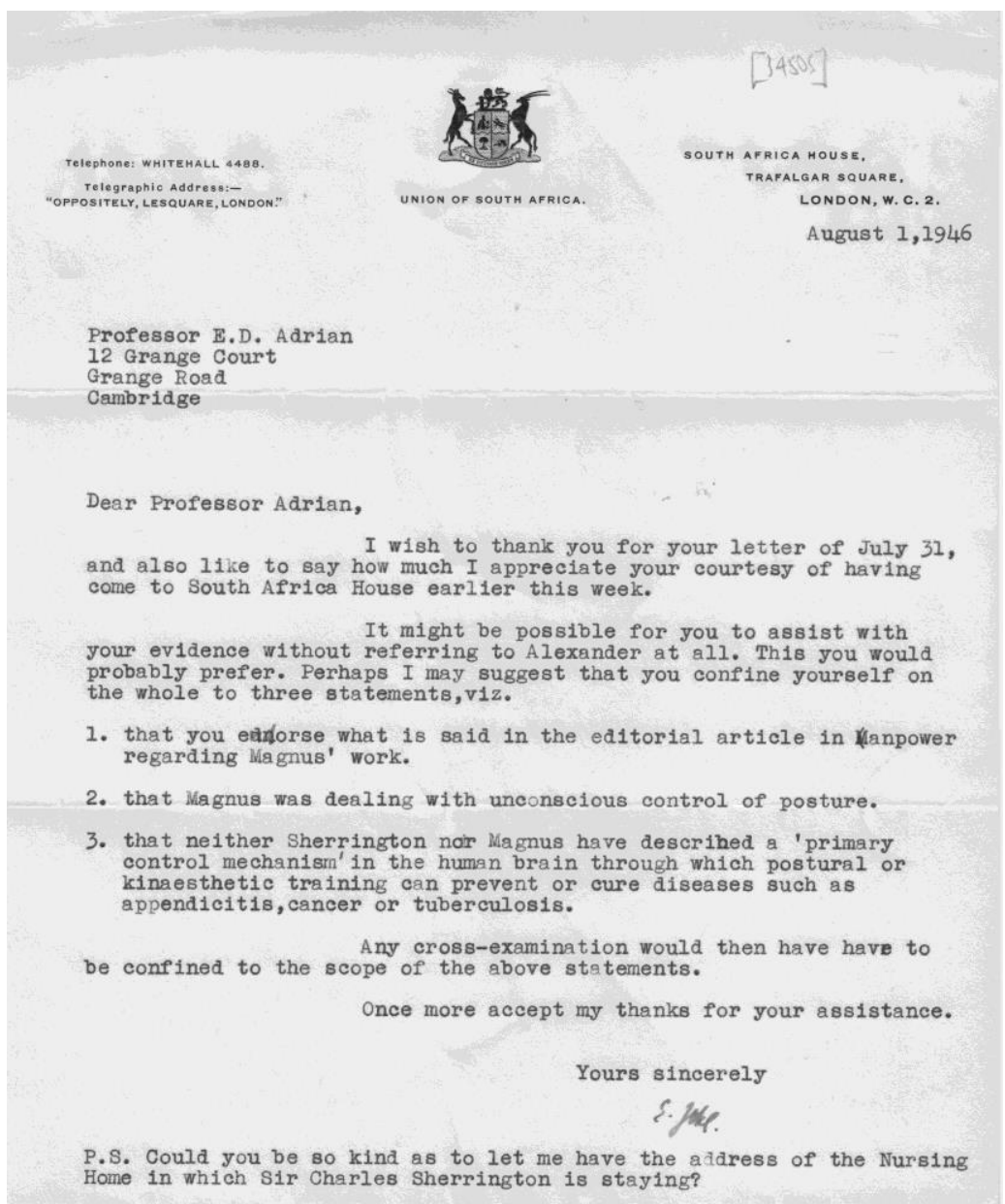

Figure 5. Letter, signed on South Africa House stationary (London), sent by Ernst Jokl to Cambridge University Professor of physiology Edgar D. Adrian, suggesting the optimal defense strategy regarding the Alexander libel case. (Jeroen Staring Collection).

The Use of the Self was not often re-edited, or reprinted during Alexander's lifetime. In the U.K., the book was released in 1931. The first edition was reprinted twice in 1932, and once in 1939. In 1941, 297 copies of this latter reprint were used to publish a Chaterson LTD 'edition.' The true second edition appeared in 1943, a third edition in 1946. That same year the book was reprinted once. It was again reprinted in 1955. In the U.S., the first edition was published in 1932; a second printing was issued in 1942.

Yet, surprisingly, Alexander's The Use of the Self, like two of his earlier books, sold on a very regular basis. This constancy had a singular reason. Each new client, before she or he would have lessons from Alexander or from one or more of his assistants, was expected to have read at least one of Alexander's books. This policy implies that books were sold on a regular basis, and cash kept flowing in, one way or another. In fact, Alexander ran a small family business, teaching his 'technique' and running a school for children with special needs. His 'company' also sold his books, his pamphlets, and, since the mid-1920s, reprints of diverse articles by others. A number of these reprinted texts were written by Alexander's physician clients, and addressed an alleged scientific confirmation by Magnus of Alexander's 'primary control' viewpoints. However, such a confirmation, notably stressed by several of Alexander's medical followers, did not exist, as was effectively shown in "Quackery Versus Physical Education," an article in the bilingual South-African physical education journal Volkskragte-Manpower (Clark, Cluver, \& Jokl, 1944) written by physician and sports physiologist Ernst Jokl, and edited by the journal's editors. Their conclusion was that "Magnus has never described or claimed anything which bears even a faint similarity to what Alexander has alleged" (p. 14). 
In a letter to the High Commissioner for the Union of South Africa in London, explaining his views regarding Magnus's 1924 book and Alexander's concept of 'primary control,' Alexander's physician client Douglas (1944) objected to the publication of the article, as well as to the choice of — in his opinion derogatory words used by its authors to describe Alexander. Alexander also objected; he later issued writ for libel against the editors of Volkskragte-Manpower. One of the expert witnesses called for the defense was Edgar Douglas Adrian (First Baron Adrian), Professor of physiology in the University of Cambridge, Cambridge, England (Shephard, 2013; see Figure 5, above), who jointly with Oxford University, Oxford, England neurophysiologist Sir Charles Scott Sherrington was awarded the 1932 Nobel Prize for Physiology.

In April 1948, Judge Henry John Clayden - Witwatersrand Local Division of the Supreme Court of South Africa - came to the conclusion that the defendants had convincingly shown that many of Alexander's so-called physiological reasons were wrong — a ruling that was not affected by a 1949 Appeal (Gordon, Turner, \& Price, 1953).

Alexander adepts (e.g., Bowden, 1957; Jones, 1953) kept referring to Magnus in spite of Judge Clayden's 1948 verdict that many of Alexander's physiological arguments were wrong. They feverishly tried to re-establish Alexander's fake scientific relationship between Magnus's 1924 views regarding the feasible existence of a neurophysiological "Zentralapparat" in the brain stem of animals and Alexander's amateur philosophical 'primary control' notions. This happened after, at long last, in 1950, that is: 25 years after the fact, Alexander's medical client Douglas confessed in a letter to the editor of the medical journal The Lancet to have merely provided Alexander with his own translation, his own understanding and his own interpretation of no more than merely page 619 in Magnus's 1924 German book Körperstellung. Akin to the Roman god Janus, Douglas showed two faces. In the concluding part of his letter, he factually took back his confession:

I provided him with a translation... and gave him what I considered to be the meaning of the passages on page 619. I understood these passages as describing the anatomical foundations of a central integrating apparatus, its manner of operation, and its place of operation in the operation of the cerebro-spinal, sensory-motor, and muscular mechanisms of the animal as a whole...I can claim no expert standing as a German scholar and may have been responsible for laying Mr. Alexander open to a charge that he relied upon a person who was not competent to guide him...Alexander may appear to stand quite alone in making his experiments and in drawing his conclusions from these experiments; but it is possible, as I contend, that he would not be quite alone were the words written by Magnus about Zentralapparat translated without prejudice. (Douglas, 1950; emphasis added).

Sure enough, four years later Douglas (1954) again advanced a connection between Magnus and Alexander, claiming, "[We] are indebted to Magnus having explained the anatomical background showing the means Mr. Alexander used while employing his own original and imaginative method, which, having in it nothing of highly specialized knowledge, may be used by the ordinary person for improving his use of the self and his control of reaction." Even after a translation of Magnus's 1924 German book Körperstellung was available (see: Magnus, 1987), other Alexander followers (e.g., Carrington, 1994; Dimon, 1999; Williamson, 2014) tried to re-establish Alexander's bogus scientific relationship between Magnus's 1924 anatomical and neurophysiological insights regarding a possible "Zentralapparat" concerning posture related centres in the brain-stem of animals, resulting from his academic experimental laboratory research, and his amateur philosophical 'primary control' concept, based solely on an unverifiable and antedated narrative.

\section{Book Reviews}

The Use of the Self was not widely reviewed in the U.K. in 1932. The few book reviews included, for instance, a very favorable, long review in the Aberdeen Press and Journal (1932). The Personalist (1932) and the Edinburgh Evening News (1932) had relative short, impartial book reviews. The Student Movement published an article by the pen of A. G. Pite (1932), head master of Weymouth College, Dorset, England and Alexander follower, mentioning the book and stressing the "idea that the human being is a unity" (p. 179). It was Pite's strong belief that Alexander's method "cannot be learnt from a book" (p. 179). Further, 
the Listener published a letter by the pen of Alexander's physician client Peter Macdonald (1932a), mentioning the book, calling Alexander a "Professor of Foresight."

A number of book reviews appeared that year in Australia (e.g., Age, 1932; Telegraph, 1932; West Australian, 1932), New Zealand (e.g., Press, 1932), as well as in the United States (e.g., New York Times, 1932). The U.S. New England Journal of Medicine (1932) was incredibly firm in its negative inference: "[Alexander's] arguments are not convincing."

Remarkably, in 1932, in England, discussions relating to Alexander's ideas in The Use of the Self filled the columns of two medical journals.

1. A first, relatively short, exchange of opinions took place in the medical weekly Medical World, between Alexander's physician client Mungo Douglas (1932a, 1932b) and Royal Army Medical Corps Major Reginald F. E. Austin (1932). Alexander did not participate. Douglas's (1932b) second letter to the editor of Medical World refers to Magnus. This first discussion is only mentioned, yet not reviewed, by Staring (2005).

2. The other, longer, debate took place in the British Medical Journal (BMJ). On April 30, the $B M J$ opened a discussion relating to The Use of the Self by issuing a favourable book review of Alexander's 1931 book (BMJ, 1932). May BMJ editions had letters to the editor by Drs McGowan (1932) and Murdoch (1932), praising Alexander's book. The June 4 BMJ edition held a letter to the editor by Dr Cawadias (1932a) fiercely criticizing the book:

Mr. Alexander, like all non-medical critics, puts the cart before the horse, and teaches treatment without diagnosis, which, of course, is impossible...In his work Mr. Alexander does not indicate any precise method of treatment. He gives a general outline of principles well known in medical circles...I do not see how the 'use of the self' will help us to cure an individual infected with typhoid fever or with cholera, or who is suffering from a perforated appendix...It is time for the medical profession to take a firm attitude against all the extramedical systems that are being proposed, systems which lack the essential condition of treatment - diagnosis.

Later, further discussion followed in June and July BMJ editions: Dr Shrubshall (1932) agreed with his confrère Cawadias's critique, Alexander (1932a) and his medical follower Macdonald (1932b) objected, while Dr Brock (1932) tried to reconcile standpoints of Alexander and Cawadias. Replies by Alexander (1932b) and by Cawadias (1932b) ended the correspondence. Note that Alexander (1932b) unambiguously stated that the existence of "the primary control... has... been conclusively proved by the experimentation of the late Rudolph Magnus of Utrecht" (p. 78; emphasis added). This second discussion is listed by Staring (2005), and is moderately reviewed by Alexander Technique teacher Fischer (in: Alexander, 1995).

\section{Book Review plus Discussion in The Yorkshire Post}

In contrast to two exchanges of opinions, indicated above, the Alexander Technique literature does not mention a 1932 book review and subsequent discussion in the Yorkshire Post. Yet, a month after Methuen \& Co. LTD (1932) placed an advertisement in the January 27 Yorkshire Post promoting Alexander's 1931 book, "Learning How to Live," a book review written by well-respected Yorkshire Post journalist Charles Davy, appeared in the February 24 edition.

We are usually ready to recognise that civilised man is inferior to animals in the instinctive harmony of his bodily functions; perhaps we seldom realise how widely this inferiority may affect his total reaction to environment. The remedy most frequently offered is "Back to Nature! - advice which no one can carry to its logical conclusion unless he is prepared to go and live in the wilds among savages. A more reasonable proposal is that we should aim at living as efficiently as animals, but on a different level - a level to be attained only by conscious thought and deliberate training.

This idea of conscious self-education is at the back of all Mr. Alexander's work, and he has already expounded it at length in "Man's Supreme Inheritance" and "Constructive Conscious Control of the Individual." In his new book he limits his aim to an outline account of the practical technique he has evolved for re-educating the body, as exemplified both in his own self-education and in his experience as a teacher of 
others. Years ago, as a dramatic reciter, he found himself gravely handicapped by recurrent hoarseness, and after laborious experiment he traced the cause of his hoarseness to faulty bodily habits which extended not only to his throat but to the posture and muscular tension of his entire body. To cure himself was extremely difficult, for ingrained bad habits had to be replaced by new, good ones, but eventually he learnt a step-by-step method of cure which he has since applied to a variety of bodily ailments in pupils of all ages who have sought his help. Impressive medical testimony to the value of his work has been given by numerous doctors, and its general scientific validity is warmly approved by Professor Dewey, himself an old pupil.

\section{Indian Parallel}

I feel sure that Mr. Alexander's discoveries are useful, and that a great deal can be expected from a fuller development of them. At times, however, his attitude - judging it only from his present book, for I have not read his earlier ones - seems to me a little narrow, or perhaps naïve is a better word. Here, for example, is a passage which he italicises:

The idea of taking the control of the use of the mechanisms of the human creature from the instinctive on to the conscious plane has already been justified by the results which have been obtained by applying it in practice, but it may be years before its true significance as a factor in human development is fully recognised.

I agree that this idea of "taking the control of the use of the mechanisms of the human creature from the instinctive on to the conscious plane" is important, but it is far from new. Precisely this idea is at the basis of the ancient and elaborate Indian system of self-discipline known as yoga - a system which in the course of centuries has been extended to embrace a far wider range of human activities than are mentioned in Mr. Alexander's book. It is this system, in a degraded form, which enables the Indian fakir to swallow coloured handkerchiefs and regurgitate them in any desired order; but it is also this system which provides a training, bodily, mental, and spiritual, directed towards fitting the pupil for scaling the most exalted heights of Indian mysticism.

\section{Stammering}

Mr. Alexander, I feel, is led by his emphasis on the word "conscious" to an unduly limited conception of the constitution of a human being. For example, he describes his successful treatment of a stammerer by means of bodily re-education, and, although such treatment may often succeed, there is much evidence to show that many cases of stammering are bound up with repression neuroses which must be dealt with on Freudian lines if a permanent cure is to result. Perhaps, since every repression may quite probably express itself bodily in the form of harmful muscular tension, it could be argued that the way to treat repressions is to relieve tensions, and an interesting field of research here offers itself; but in the present state of our knowledge a discussion of stammering which makes no reference to psycho-analysis cannot be accepted with entire confidence.

\section{Athletic Training}

This is only one of several sections of the book which makes one feel it has been written by a craftsman rather than a philosopher. After all, in the bare idea of conscious self-training there is nothing very original, for every athlete trains himself by taking thought before he reaches the stage of unconscious mastery; and the value of Mr. Alexander's work is to be found, I think, rather in the details of his training technique and its medical applications. But here, again, his outlook seems to be oddly limited, for in this book, at any rate, he sometimes writes as though conscious self-control were the ultimate ideal, whereas the athlete example I have just quoted is enough to remind us that bodily control is never finally efficient until consciously-acquired lessons have sunk into the unconscious - until, that is, a good style has become a natural habit. And it is surely obvious that any adequate system of self-discipline must, in the end, stretch in many directions far beyond the conscious level.

These criticisms, however, may be unfair to Mr. Alexander's general attitude as expressed in his earlier writings, and in any case the practical utility of his new book remains. There is great need to-day for a Western yoga, adapted to western needs and in accord with modern science, and any step towards the extension of such a system is valuable - so long as it does not lead us to a superficial view of human personality and human destiny. This danger is present, it seems to me, in Mr. Alexander's book, and the remedy for it is more imagination - a remedy which would also help to lighten his rather laborious style. But his book - quite a short book - is convincingly sincere and pleasantly unassuming in tone. It is well worth the attention of all who share Professor Dewey's opinion that "the control we have gained of physical 
energies, heat, light, electricity, etc., without having first secured control of our use of ourselves, is a perilous affair." (Davy, 1932a).

Alexander took action a few weeks later. His never previously cited letter to the editor of the Yorkshire Post, dated March 21, appeared in the March 30 edition of the newspaper.

Sir, - I thank you for allowing so much space to the review of my book "The Use of the Self," but I regret that the comments of your reviewer, Mr. Charles Davy, show that he has not grasped the principle underlying my technique. This is the more unfortunate, as on Page 46 of my book I asked that "the practical procedures which I am now putting forward" should "be judged by the principle which underlies them." Mr. Davy courteously intimates that his "criticisms may be unfair to my (Alexander's) general attitude," but it is on the point of principle that I claim that he mis-represents (though I am certain unintentionally) the subject matter of my book.

First, Mr. Davy comments imply that his conception of "use" is more limited than that inherent in the definition of "use" that I gave on Page 4, where I stated that "when I employ the word 'use' it is not in that limited sense of the use of any specific part, such as, for instance, when we speak of the use of an arm, or the use of a leg, but in a much wider and more comprehensive sense applying to the working of the organism in general." This criticism also applies his employment of the term "conscious control," for in this case also I set down my conception of the phrase when I wrote in "Man's Supreme Inheritance," Page 40, that in my work "the phrase 'conscious control' is intended to indicate the value and use of conscious guidance and control primarily as a universal and, secondly, as a specific, the latter always being dependent upon the former in practical procedure."

But what bears out most fully my contention that Mr. Davy has not grasped the principle underlying my technique, is that in a careful reading of his review one fails to find any reference to the fact that in the course of the experiments and experiences descriped $[\mathrm{sic}]$ in Chapter $1 \mathrm{I}$ was led to the discovery of a primary control of the psycho-physical mechanisms (a discovery verified by the late Randolph [sic] Magnus). Through the experiences described I made the further discovery that the "feeling" by which I was guiding myself in my efforts to improve my use was untrustworthy and was leading me into error. Having reached this point I saw that it was necessary for the time being to abandon directing myself by "feeling," and to substitute for this direction a new conscious reasoning direction of my use. By this plan all results were gained in process, by indirect, not by direct, means, and the proof that I was really using conscious direction in this sense was that when at last I saw in the mirror that I was gaining the result I desired, I "felt" I was not gaining it; in other words, what I was doing "felt wrong" to me.

I put it to Mr. Davy that the process of conscious direction of a primary control through which the psychophysical mechanisms are indirectly controlled, and in which the subject is actually doing what feels wrong to him in order to gain the result he desires is a process based upon a totally different principle from that which underlies the system of the Yoga, with which he parallels my work, or, indeed, any of the methods of athletic or other training, or of therapeutics, such as psycho-analysis, to which he makes reference. Nor have the experiences associated with the working out of this process ever been recorded in connection with any of these systems. The significance of these experiments and experiences seems to have escaped Mr. Davy, so perhaps I may be allowed to quote what William Soskin has written concerning them when reviewing my book in the "New York Evening Post" of January 14, 1932:-

"He is the first man, so far as I know, who consciously and deliberately set out to will his own self, by strictly scientific and non-mystic, non-Yogi, non-Humanist methods into another being."

Yours, etc.

F. Matthias Alexander.

16, Ashley Place, S.W., March 21. (Alexander, 1932c).

Note how crotchety Alexander explained the reason why Davy may have possibly misunderstood the meaning of the phrases 'use' and 'conscious control' in The Use of the Self - two terms, commonly used, to which Alexander had attached his own definitions, respectively in his 1931 The Use of the Self and in the 1918 Man's Supreme Inheritance.

As regards Alexander's thoughts about 'conscious control,' first uttered in the 1910 edition of Man's Supreme Inheritance, two years later also in his book Conscious Control, and again in the 1918 edition of 
Man's Supreme Inheritance, it must be reminded that Davy in his book review explicitly stated he had not read Man's Supreme Inheritance (see above). Even so, Alexander referred to his own particular definition of 'conscious control' in the (at the time) 14 years old 1918 edition of Man's Supreme Inheritance as if Davy knew the specific definition of the phrase. (N.B. Alexander stated his quote stems from page 40; however it is in page 57.) Furthermore, it must be clear that Alexander merely addressed Davy's comments regarding the terminology in The Use of the Self. On the other hand, Alexander's reply definitely did not enable the majority of the average Yorkshire Post readers to form whichever rational understanding of what Alexander was trying to convey.

Note too how self-centred Alexander (1932c) wrote about Magnus in his letter to the editor of the Yorkshire Post: "I was led to the discovery of a primary control of the psycho-physical mechanisms (a discovery verified by the late Randolph [sic] Magnus)." Not only did he 'misspell' Magnus's first name, Randolph instead of Rudolf, he also literally stated that Magnus had verified his alleged "discovery of a primary control of the psycho-physical mechanisms." Only four months later he would state in the British Medical Journal that the existence of "the primary control...has...been conclusively proved by the experimentation of the late Rudolph Magnus of Utrecht" (Alexander, 1932b, p. 78; emphasis added; see above). It must be noted, equally, that this kind of conceit regarding Magnus in particular, and physicians in general, persistently returns in the works of a number of Alexander's followers and in the works of quite a few Alexander Technique teachers.

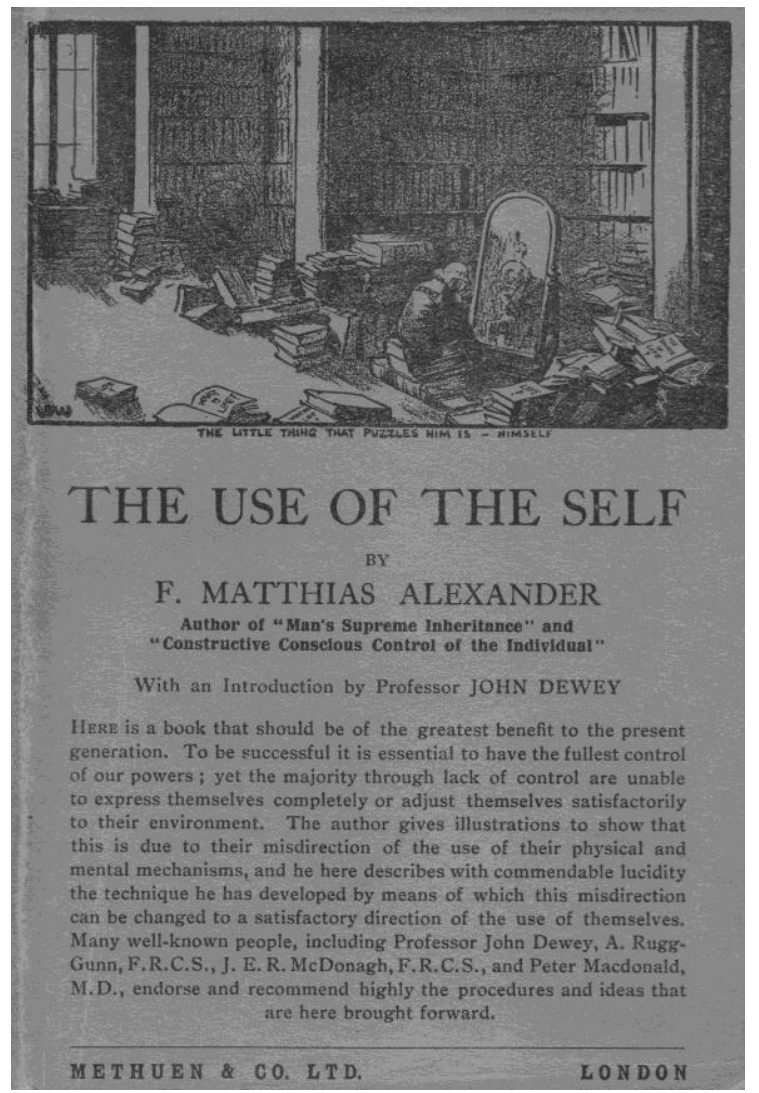

Figure 6. Front of dust jacket of the January 1939 reprint of the first U.K. edition of The Use of the Self, used for the 1941 Chaterson LTD 'edition.' (Jeroen Staring Collection).

According to what Alexander had pointed out in his letter to the editor of the Yorkshire Post, the New York City Evening Post had indeed published a book review by famed research psychologist William Soskin (1932), He, like Yorkshire Post journalist Davy, indicated in his book review that he had not read Alexander's earlier books Man's Supreme Inheritance and Constructive Conscious Control of the Individual. What is more, his words (cited by Alexander) must be understood as ironic, and most certainly not humorless. The following quote of the complete opening paragraph of his book review in the January 14 , 1932, Evening Post will illustrate this deduction: 
An intimation of biological importance hovers about the person of Dr. [sic] F. Matthias Alexander, such importance as very few living organisms have attained. The unicellular animal that decided to devote some of its protoplasmic energy to attaching an annex unto itself instead of lazily dividing in two had that importance. The fish who found himself on land one sunny day and decided to make a go of it instead of returning to the wet contributed to the biological evolution, the important tradition served by Dr. Alexander. He is the first man, so far as I know, who consciously and deliberately set out to will his own self, by strictly scientific and non-mystic, non-Yogi, non-Humanist methods, into another being. (Soskin, 1932; emphasis added).

The biological evolutionary mechanisms as wittily 'pointed out' ( 'deciding,' 'willing') do not exist in the actual world. Moreover, it turns out that Soskin was not won over at all by Alexander's reasoning. Soskin made this perfectly clear in the closing section of his book review, referring to Alexander's "hypotheses" as "inductive reasoning."

I had hoped that Dr. Alexander would develop in specific detail some of his actual applications of the "Use of the Self" in his London school. His essays rarely depart from the theoretical considerations involved and his eagerness to demonstrate the soundness of his inductive reasoning leads to much repetition. One hopes, however, that with the development of laboratory applications and concrete cases of his method in education, the apparent promise of his hypotheses will be fulfilled. (Soskin, 1932).

Since the overwhelming majority of Yorkshire Post readers would not at the same time be readers of the American newspaper Evening Post, Alexander must have felt confident his sophisms intended to trump book reviewer Davy and Yorkshire Post readers worked perfectly.

Davy replied to Alexander's objections. In a short text, printed in black and white underneath Alexander's letter to the editor, he put his finger on a number of sore spots, among these, convincingly, the nature of modern learning methods of athletes:

I am sorry that Mr. Alexander should feel I have misrepresented him. But I do not think that anyone reading simply "The Use of the Self" - I said in my review that I had not read Mr. Alexander's previous books will be easily convinced of the absolute novelty claimed by Mr. Alexander for the principle underlying his methods. Athletes, for example, are quite accustomed to learning methods which at first "feel" wrong; and in these days of slow-motion films and intensive technical coaching, they are certainly not dependent solely on "feeling" for directing their training.

I suggested in my review, the practical details of Mr. Alexander's method may well be both new and valuable, but the book does not attempt a full exposition of these details, which can probably be satisfactorily explained only by personal demonstration. And the account of "primary control" seems to me scarcely illuminating enough, in itself, to give much scope for useful comment.

As to Yoga, if Mr. Alexander sets so much store on those aspects of his system which distinguish it from Yoga, why is not Yoga discussed and the distinction brought out? As to psycho-analysis, would Mr. Alexander claim that all cases of stammering can be cured by his system without recourse to psycho-analysis. If so, he should make this claim in his book. If not, he should recognise the existence of psycho-analytic methods, which might well supplement his system without opposing it. (Davy, 1932b).

\section{Inference}

This case study describes how tenaciously Frederick Matthias Alexander, founder of the Alexander Technique, assisted by a number of his clients and (former) students, was trying to introduce his 'inhibiting,' 'feeling,' 'primary control,' 'projecting conscious directions,' 'use,' and other quasi-physiological ideas within the professionalized medical world since the mid-1920s. Alexander's tenacity evolved in pace with the development and expansion of his teachers training course that began in May 1931, and, consequently, with the derivative admiration of a growing number of his followers. The tenacity even grew after Judge Clayden's verdict in the South-African libel case, in 1948: many of Alexander's alleged physiological arguments were plainly wrong. Interesting in this context: neither Alexander nor his followers have ever attempted to negotiate the meaning or definition of his many neologisms, or his own particular explanation of commonly used words, terms, phrases and concepts. Today's Alexander Technique teachers bear the consequences of Alexander's strategy of self-sought isolation. They are perceived as belonging to a sect or cult (Becker, 1976; Staring, 2005) with its own closed, estranged vocabulary, and its own, also closed 
citation community, while they are never worried about the lack of critical transparent communication with scientists, pedagogues, physicians and physiotherapy practitioners.

The prediction in the 1927 English newspaper The Daily Chronicle that Alexander "may end by revolutionizing medical science" (H. F., 1927; see above) has logically not come true - essentially as a result of Alexander's own stubbornness to not want to negotiate his phraseology and the meaning and definition of his neologisms. Alexander's (1932c) letter to the editor of the Yorkshire Post constitutes a perfect textbook example of his stubbornness.

\section{References}

(The) Aberdeen Press and Journal. (1932, February 27). Why Doesn't the Golfer Keep His Eye on the Ball?, p. 6.

(The) Age. (1932, April 23). The Science of Self, p. 19.

Alexander, F. M. (1907). The Theory and Practice of A New Method of Respiratory Re-Education. London: Baillière, Tindall and Cox.

Alexander, F. M. (1910). Man's Supreme Inheritance. New York: London: Methuen \& Co., LTD.

Alexander, F. M. (1911). Man's Supreme Inheritance (Addenda). London: Methuen \& Co., LTD.

Alexander, F. M. (1912). Conscious Control. London: Methuen \& Co., LTD.

Alexander, F. M. (1918). Man's Supreme Inheritance. New York: E. P. Dutton \& Company.

Alexander, F. M. (1925). An Unrecognised Principle in Human Behaviour. (Address given to the ChildStudy Society; 19 February 1925). Unpublished manuscript of transcript of the lecture.

Alexander, F. M. (1931). The Use of the Self. London: Methuen \& Co., LTD.

Alexander, F. M. (1932a). The Use of the Self. The British Medical Journal, 1932-i(3728), pp. 1149-1150.

Alexander, F. M. (1932b). The Use of the Self. The British Medical Journal, 1932-ii(3731), pp. 77-78.

Alexander, F. M. (1932c, March 30). "The Use Of The Self." The Yorkshire Post, p. 5.

Alexander, F. M. (1945). Comments cited in page 2 of a 2-page text, "Lessons in the Application of F.M. Alexander's Principle Of Primary Control to Individual Problems," by F. P. Jones, probably December 1945. Text kept in the F. Matthias Alexander \& Frank Pierce Jones Special Collection; Special Collections, Wessell Library, Tufts University, Medford.

Alexander, F. M. (1995). Articles and Lectures. London: Mouritz.

Alexander, F. M. (n.d.). Mr. F. Matthias Alexander - Specialist in Respiration. London: Knapp, Drewett \& Sons, LTD.

Austin, R. F. E. (1932, September 16). Nutrition and Living Habits. Medical World, p. 58.

Becker, E. (1976). The Denial of Death. New York: MacMillan Publishing Company.

Bloch, M. (2004). F. M.: The Life of Frederick Matthias Alexander, Founder of the Alexander Technique. London: Little, Brown.

BMJ. (1932). "The Use of the Self." The British Medical Journal, 1932-i(3721), p. 808.

Bowden, G. C. (1957). Some Talk of Alexander with an Interpretation of his New Way of Life. Palma de Mallorca: Mossèn Alcover Press.

Brock, A. J. (1932). The Use of the Self. The British Medical Journal, 1932-i(3729), p. 1192.

Carrington, W. (1994). The Foundations of Human Well-Being \& The Work of Professor Magnus and the F. Matthias Alexander Technique. London: STAT Books.

Casey, A. (1985, April 21). 'Long John' shuns his wealthy past — for a barge home. The Sun-Herald.

Cawadias, A. P. (1932a). The Use of the Self. The British Medical Journal, 1932-i(3726), p. 1056.

Cawadias, A. P. (1932b). The Use of the Self. The British Medical Journal, 1932-ii(3731), p. 78.

(The) Christian Advocate. (1918, May 2). A British Methodist Ambassador, p. 562.

Clark, B. M., Cluver, E. H., \& Jokl, E. (1944). Kwaksalwery Teen Liggaamlike Opvoeding / Quackery Versus Physical Education. Volkskragte-Manpower, 2(2), pp. 2-45.

Davy, C. (1932a, February 24). Learning How To Live: Conscious Training of Body and Mind. The Yorkshire Post, p. 6.

Davy, C. (1932b, March 30). "The Use Of The Self." The Yorkshire Post, p. 5.

Dewey, J. (1910). How We Think. Boston, New York, Chicago: D. C. Heath \& Co., Publishers. 
Dewey, J. (1918). Introductory Word. In F. M. Alexander, Man's Supreme Inheritance (pp. xiii-xvii). New York: E. P. Dutton \& Company.

Dewey, J. (1923). Introduction. In F. M. Alexander, Constructive Conscious Control of the Individual (pp. xxi-xxxiii). New York: E. P. Dutton \& Company.

Dewey, J. (1931). Introduction. In F. M. Alexander (Ed.), The Use of The Self (pp. xiii-xix). London: Methuen \& Co., LTD.

Dimon, T. (1999). The Undivided Self. Berkeley, California: North Atlantic Books.

Douglas, M. (1932a, September 9). Nutrition and Living Habits. Medical World, p. 38.

Douglas, M. (1932b, October 7). Nutrition and Living Habits. Medical World, p. 117.

Douglas, M. (1944, November 19). Original carbon copy of unpaginated four-page letter from Dr. Mungo Douglas to The High Commissioner for the Union of South Africa. Kept in the Jeroen Staring Collection, Nijmegen, The Netherlands.

Douglas, M. (1950). The Alexander Libel Action. The Lancet, 256(6622), p. 197.

Douglas, M. (1954). Control of Reaction. The Lancet, 263(6802), p. 156.

(The) Edinburgh Evening News. (1932, February 8). The World of Books: "The Use of the Self," by F. Matthias Alexander, p. 9.

Eugenical News. (1916, October). Heredity of C. W. Saleeby, pp. 70-71.

Gordon, I., Turner, R., \& Price, T. W. (1953). Medical Jurisprudence (Third ed.). Edinburgh and London: E. \& S. Livingstone LTD.

H. F. (1927, March 5). Is It Our Own Fault? The Daily Chronicle.

Jones, F. P. (1953). Psychophysical Reeducation and the Postural Reflexes. (A Paper read at the Science Weekend at Bard College, Annandale-on-Hudson, N.Y., May 9, 1953). Unpublished manuscript, kept in the F. Matthias Alexander \& Frank Pierce Jones Special Collection; Special Collections, Wessell Library, Tufts University, Medford.

Jones, F. P. (1979). Body Awareness in Action. New York: Schocken Books.

Ludovici, A. M. (1933). Health and Education Through Self-Mastery. London: Watts \& Co.

Ludovici, A. M. (1945). The Four Pillars of Health. London: Heath Cranton Limited.

Macdonald, P. (1932a, December 14). A Professor of Foresight. The Listener, p. 868.

Macdonald, P. (1932b). The Use of the Self. The British Medical Journal, 1932-i(3728), p. 1149.

Macdonald, P. J. (1936). Physical Education. The British Medical Journal, 1936-i(3938), p. 1332.

Magnus, R. (1924). Körperstellung. Berlin: Verlag von Julius Springer.

Magnus, R. (1987). Body Posture. New Delhi, New York: Amerind Publishing Co.

McGowan, R. G. (1932). The Use of the Self. The British Medical Journal, 1932-i(3723), p. 912.

Methuen \& Co. LTD. (1932, January 27). The Use of the Self. (Advertisement). The Yorkshire Post, p. 6.

Murdoch, A. (1932). The Use of the Self. The British Medical Journal, 1932-i(3725), pp. 1009-1010.

(The) New England Journal of Medicine. (1932). The Use of the Self. By F. Matthias Alexander, 207(1), p. 47.

(The) New York Times. (1932, 16 January 1932). Dewey Urges Need For Self-Control.

Pite, A. G. (1932, May). Using Yourself. The Student Movement, pp. 178-179.

(The) Press. (1932, April 2). Human Behaviour, p. 11.

R. M. (1928, November 15). Views and Reviews. Constructive Re-education. The New Age, pp. 31-32.

Rugg-Gunn, A. (1940, April 3). F. Matthias Alexander and the Problem of Animal Behaviour. The Medical Press and Circular, pp. 285-287.

Saleeby, C. W. (1904). The Cycle of Life According to Modern Science. New York \& London: Harper Brothers Publishers.

Shakespeare, W. (1924). Plain Words on Singing in the Absence of a Master. New York: G. P. Putnam's Sons.

Shephard, R. J. (2013). Historical Perspective. The developing understanding of Human Health and Fitness:

8. The Modern Era. Health \& Fitness Journal of Canada, 6(3), pp. 3-113.

Shrubshall, W. W. (1932). The Use of the Self. The British Medical Journal, 1932-i(3728), p. 1150.

Soskin, W. (1932, January 14). Reading and Writing. New York Evening Post, p. 11.

Starch, D., Stanton, H. M., \& Koerth, W. (Eds.). (1936). Controlling Human Behavior. New York: The MacMillan Company. 
Staring, J. (1990). Facts About Mr. Alexander's Private Life In Their Proper Context. London: Society of Teachers of the Alexander Technique (STAT).

Staring, J. (2005). Frederick Matthias Alexander 1869-1955: The Origins and History of the Alexander Technique. Nijmegen: Integraal.

Staring, J. (2015). F. M. Alexander and the Bureau of Educational Experiments. International Journal of Case Studies, 4(9), pp. 1-18.

Staring, J., Bouchard, E., \& Aldridge, J. (2014). New Light on the History of Walden School. International Journal of Case Studies, 3(9), pp. 1-21.

The F. Matthias Alexander Trust Fund. (1935). A New Technique Employed in Acquiring an Improved Use of the Self while Learning and Learning to Do. London: C. A. Watts \& Co. Limited, and The F. Matthias Alexander Trust Fund.

(The) Telegraph. (1932, March 19). On Human Misdirection, p. 6.

(The) West Australian. (1932, March 12). Individual Control, p. 4.

Williamson, M. (2014, Spring). How did the concept of 'primary control' evolve during Alexander's lifetime? In the Moment, pp. 7-15.

Yearsley, M. (1925). Man's Future (Reprint from "The Literary Guide," October, 1925). London: Methuen \& Co., LTD. 